Helena Vad'urová, Victoria Shmidt

\title{
Personal assistance to people With ASd IN CZEChia: BETWEEN POSITIVE DISCRIMINATION AND ABLEISM
}

Contemporary politics concerning those with Autism Spectrum Disorder (ASD) revolves around a contest between the medical perspective of autism as a pathology in need of a cure and the autism acceptance perspective, which maintains that autism is a normal human variation. Neither of these extremes provides a sustainable solution to the dilemma of empowerment and care for the people with ASD. Even more, each of the extremes runs the risk of reproducing ableism, a cultural status quo that privileges an able-bodied 'norm' and re-establishes hierarchies of ability upon people with ASD. The call for personal assistance, a pillar of independent life for people with disabilities, reframes the policy of the individual approach for people with ASD by ensuring better continuity between assessment and intervention. The current $\mathrm{Czech}$ policy concerning people with disabilities remains aligned with the approach introduced in the late 1980s that divides people with disabilities into categories according to the degree of their dependence instead of refining the approach in line with needs assessment and individualizing interventions. How do different actors respond to the obvious lack of personal assistance to people with ASD? This article examines the impact of governmental bodies responsible for disability policy, the regional authorities and civil society actors on reproducing post-socialist path dependence on medicalised assessment, the centralised approach to funding, and the univocity with residential care. We apply the 'Assessing Personal Assistance Schemes', a multi-faceted set of criteria aimed at monitoring the right to independent life, for indicating options concerning sustainable switching to personal assistance.

Helena Vad’urová- Ph.D, Assistant Professor, Vice-dean for Quality and Strategy, Institute for Research of Inclusive Education, Faculty of Education, Masaryk University, Brno, Czech Republic. Email: vadurova@ped.muni.cz

Victoria Shmidt- Ph.D, Senior Post-doctoral Researcher, Institute for History, University of Graz, Graz, Austria. Email: victoria.shmidt@uni-graz.at 
Key words: people with ASD, post-socialist politics of disability, personal assistance, positive discrimination, ableism

DOI: $10.17323 / 727-0634-2019-17-4-629-642$

\section{Introduction}

The traditional, medical perspective, which is derived from considerable scientific and educational research, views autism as a pathology in need of a cure (Lim 2015). In contrast to this formerly taken-for-granted attitude, the autism acceptance movement maintains that autism is a normal human variation that should be accommodated by the informed mainstream. According to the autism acceptance perspective, ableism, a main output of the medical model, is the central obstacle for the integration of neurodiverse individuals (Cage et al. 2018). Parallel to sexism and racism, ableism is a cultural status quo that privileges an able-bodied 'norm' and systematically denies equality for those who fall outside this norm (Gobbo, Shmulsky 2016).

Beyond these two extremes, a pragmatic view of the strategies aims at achieving a balance between empowerment and care for people with Autism Spectrum Disorder (ASD), taking into account the insights of both the medical and social models. Andrew Solomon (2012:249), who recognizes autism as a blanket term, calls for a more sensitive approach to solving the contest between the medical model and disability studies in the case of autism. The ambiguous view on neurodiversity emphasizes neglecting the challenges experienced by those who live with the most severe forms of ASD (Jaarsma, Welin 2012; Solomon 2012), which may preclude independent living and be accompanied by related medical issues such as seizure disorders, gastro-intestinal conditions, obesity, and insomnia: 'Acceptance does not "cure" difficulties with social relationships, social communication, rigidity and sensory issues' (Jaarsma, Welin 2012:303). But how to arrange the different forms of ASD and avoid the threat of ableism that tends to operate under a kind of hierarchy according to the degree of possibility of integration for people with ASD? Or in the words of Wendy Lawson (2008), a person who sees ASD from an inside perspective, how do we take into account the 'diffability' of people with ASD?

This challenge can be seen as the main reason why, according to the legal experts, 'it is not realistic to expect European States or European political institutions to draft and adopt in the very next years a European convention or a hard-law act on the rights of persons with autism' (Palmisano 2015:21). Mainly, the institutional response to the needs of people with ASD and their families operates at national level- by challenging the approaches to organizing the assessment of needs and gradually shifting the system towards the ideal of individualised combination of care and empowerment.

The call for developing personal assistance, one of the pillars supporting independent life for people with disabilities, together with the choice of living 
arrangements, de-institutionalization, quality of social services and income maintenance, can be seen as partially determined by the necessity of elaborating on an approach that can take account of the needs of people with ASD. In Sweden, Netherlands, and Germany, introducing personal assistance relies heavily on promoting the needs of people with ASD and their family members. It is possible to say that personal assistance bridges the positive discrimination of people with ASD with its inevitable risks of objectifying them and the general trend to stop perceiving people with ASD as the recipients of charity but rather accepting them as holders of rights.

Personal assistance and its core financial mechanism, the personal budget- 'earmarked cash allocations for disabled people allowing them to pay for any assistance needed' (ENIL 2016:2) - has achieved the top position in the transformation of services in more than twenty European countries. Czechia is one of the European countries still standing on the margins of the European mainstream in terms of personal assistance. Even more, the Czech concept of osobni asistence refers to a particular type of service, a person called a 'personal assistant' who provides care to a person with disabilities. This is not in line with the entire strategy claimed at the level of EU. State policy concerning people with disabilities continues to reproduce the approach introduced in the late 1980s aimed at dividing people with disabilities into categories according to the degree of their dependence, instead of refining the approach in line with needs assessment and individualizing interventions. This division infiltrates all realms of social provision: the approach to social benefits, the access to care facilities, planning the state and local budgets, and the civil initiatives of the non-government sector.

How do different actors respond to the obvious lack of personal assistance to people with ASD? This text aims to remap the current state of personal assistance to people with ASD in Czechia in terms of the limits and the options for elaborating a sustainable multilevel policy adequately implementing the rights of this target group.

\section{Methods and sources}

We apply the criteria and indicators developed by Teodor Mladenov (2016) to interpret the activities of the main actors in policy making around people with ASD. Assessing Personal Assistance Schemes (APS) offer a multi-faceted set of criteria aimed at monitoring the implementation of Article 19 of the UN Convention on the Rights of Persons with Disabilities (CRPD) - 'living independently and being included in the community'.

While expert opinion is the most decisive for the efficient application of the APS, the main challenge is to provide a comprehensive mapping of the actors whose participation and stances balances the mainstreaming of disability in all initiatives/projects, on the one hand, with disabilities-specific initia- 
tives/projects, on the other (OHCHR 2010). In Czechia, the central government decides on the size of the budget for social services for individual regions. It is the regional government that then allocates finance to individual social services providers. However, in Czechia, no government agency collects evidence of the population of people with ASD, which is a great barrier to appropriate service planning. This is mirrored in the activities of the civic actors which are to a certain degree driven by their local needs. The palpable difference in the rhetoric from the side of civil initiatives to address either central/state agencies or local authorities reinforces the triangulation of the actors also as a suitable model for exploring the latter in mutual communication - the core process of advancing various approaches to social provision for the people with ASD.

One of the central sites of this communication is the Professional Board for conceptual solutions to the issues concerning the life of people with ASD (Odborná skupinu pro koncepční ř ěsení problematiky života osob s poruchou autistického spektra) established by the Governmental Commission for Citizens with Disabilities (Vládní výbor pro zdravotně postižené občany) in 2014. Martina Štěpánková, the deputy of the Commission, leads the Board. The representatives of the Ministries, medical experts and influential professional unions are the members. However, since 2016, after issuing the Public Statement 'Toward solving the issues of the people with ASD' (Podnět $k$ rešeni situace života osob s poruchou autistického spektra a jejich rodin) with particular focus on informing the public and involving civil society, the Board has involved nongovernmental organizations (mainly parental units). The Board organizes two meetings annually, and the minutes of the meetings are a key source for examining the approaches to the needs and rights of people with ASD.

Another important site is the communication between the Human Rights Ombudsman Anna Šabatová and the regional authorities concerning monitoring under the regional policy around people with ASD. In 2017, the office of Human Rights Ombudsman conducted a survey among people with ASD and their family members in order to indicate the current state of social provision (Veřejný ochránce 2018a). After this, Ombudsman sent questionnaires to regional authorities and requested a report about their plans and strategies aimed at ensuring access of people with ASD to social provision. Eleven out of fourteen regions presented their experience and reflections concerning the issue of social provision for this target group.

The third site of communication is policy papers prepared by non-governmental organizations in order to facilitate the dissemination of best practice for people with ASD. In 2018, the parental unit 'Children of the Full Moon' (Děti úplňku) published a comparative analysis of the accessibility of services for people with ASD (2018). The National Institute of Autism (Národní ústav pro autis$m u s$ ), the largest non-government networking of professionals who work with children with ASD and their families, disseminated the report developed in 2017. Both reports stemmed from juxtaposing the survey among the parents of people with ASD and the services providers. 
The main components of the APS for assessing personal assistance are: contexts, funding, needs assessment, and the provision of services are applied to recent developments in Czech policy-making and in the key topics of communication among the actors.

\section{Historical roots and the current issues of ableism}

Contexts map the options for society to participate in personal assistance schemes and accept shared responsibility for implementing the right of people with disabilities to independent life. According to Mladenov (2016), one of the most important prerequisites for the efficient operation of personal assistance is establishing itself as the outcome of disabled people's advocacy. The policy concerning people with disabilities in Czechia continues to take a top-down approach and reproduce consistent ableism of people with disabilities.

The post-socialist policy accepted the legacy of the late socialist period that divided people with disabilities into those who had 'partial, significant and total disempowerment' (částečná, prevážná, úplná bezmocnost). After 1989, this division was supplemented by the system of special identification documents (IDs) indicating the severity of one's disability and thereby entitling the holder to a certain amount of outstanding benefits (mimořádné výhody): 'profound disability needing an accompanying person' (zvlášt' těžké postižení s průvodcem); 'profound disability' (zvlášt těžké postiženi); and 'severe disability' (těžké postiženi). All three types of IDs include various social, economic, transportation, and cultural advantages and discounts for holders (Sinecka 2007). In the early 2000s, under international pressure, the approach to differentiating people with disabilities was revised towards becoming more relevant to the contemporary policy of inclusion: people with disabilities were categorised into four groups according to the degree of dependence on care by a third person and the amount of benefit has increased three-fold since 2006 (MPSV 2007). While this 'nuanced' scheme started to be applied to decisions about care benefits, the previous three-grade division continues to be used to regulate access to other privileges. The co-existence of these two schemes is one of the most visible signs of reproducing ableism in the form of building hierarchies of those with disabilities according to their capacities to be integrated into society.

Though differentiation of people with disabilities is not the subject of consistent critique, its inefficiency concerning people with ASD is one of the central motives of debates among members of the Governmental Board. The main concern is the impossibility to use the existing differentiation with the aim of gathering data concerning people with ASD and improve public competencies. At one of the first meetings of the Board, Iva Dudová, a key medical expert on autism, noted that 'The division does not have any diagnostic grounds' (Odborná skupina $2015 \mathrm{a}$ ). Along with this critique, the Board stressed the obstacles for people with ASD in getting the ID relevant to the degree of their disability. 
For instance, parents are entitled to financial support for a car in order to improve their mobility only if their child is diagnosed with an intellectual disability (Odborná skupina 2019).

Thus, one of the earliest initiatives of the Board was to introduce a special ID for an individual with ASD (prikaz osoby s PAS) comparable to the system of such IDs in the UK, USA, and Australia, which enables the holders to identify themselves to others as having ASD. According to the Ministry of Health (2016) the ID should contain information about the holder, which would 'promptly and univocally inform those who come in contact with the holder about his/her specific needs and the approaches towards communication' (komunikačni profil). The main argument in favour of introducing this system was 'the outstanding degree of specific behaviour that prevents not only ordinary people from recognizing the proper way of communicating with people with ASD but those who are in their professional duties: physicians, policemen, firefighters' (Ministerstvo zdravotnictví 2016). Tellingly, the Autism ID cards should divide individuals into categories as well: able and unable to provide verbal communication (verbálně (ne)zdatný).

The introduction of the Autism ID card in the USA brought a mixed response from those who have ASD (Autism Policy and Politics 2015). Along with the fear of being labelled, some people with ASD recognize in the ID cards system the risk of surveillance. In the minutes of the Board there are no signs of reflecting on this threat. Quite the opposite, during one of the meetings all members agreed that each person diagnosed as having ASD should be obliged to get the card but probably be free to make a decision on its use (Odborná skupina 2015c).

The ongoing debates around the Autism ID reveal the intention of actors to exaggerate positive discrimination by stressing the outstanding needs and specifics of people with ASD. Indeed, emphasizing the enormous barriers faced by caregivers can be easily read as labelling people with ASD in terms of otherness: 'Social workers cannot work with this target group, field work with ASD is extremely complicated, and the expectations of professional care are totally different in contrast to other groups' (Odborná skupina 2015b).

Partially, the rhetoric of otherness serves to introduce the public to the issue; for instance, Déti úplňku (2017) directly oppose the perception in American movies of people with ASD as gifted albeit strange characters as opposed to real children with challenging behaviour: 'While you link autism with the main character in Rain Man, you could not recognize it in our children. Well, some of them have particular gifts that deserve attention, but most of all they have an enormous handicap in recognizing our world and the ability to operate within it'. Also, using positive discrimination remains an ambivalent strategy. Those who attack the efforts to improve social provision for people with ASD, mainly physicians, directly mention that ASD is a fashionable diagnosis which is currently overused (Slepičková et al. 2019) or even that 'to have a child with a ASD today means a fast track to money and benefits' (Matýs 2017). 
Oscillating between positive discrimination and the attempts to overcome public ignorance is reflected in the approaches to statistical data concerning the number of people with ASD, especially those with challenging behaviour. According to non-governmental organizations, the number of those who have ASD with strong manifestations of challenging behaviour is between 2,000 (Křečková, Šimáček 2018) and 4,000 (Jůn, Thorová 2017). Probably, this remarkable difference is determined by the obviously different intentions of those who use statistical arguments to advance their approach. Those who univocally advocate the priority of care keep numbers lower, while those who recognize the risk to subsidiarity from the side of such a strategy are not afraid to give higher numbers also in order to inform the public about the potential impact of civil participation on improving access to community care. Multiplying ableism orchestrates other realms of the policy concerning people with ASD and the specific pathway of decentralizing funding, fixing the monopoly of medical approaches to assessing the needs, and the priority given to residential care in providing such services.

\section{Funding: monopolised by the state}

The share of the budget for people with disabilities in relation to the entire budget for social protection remains among the most modest. Only social protection of those who live in socially vulnerable districts - mainly the Roma population- receives less funding. The budget for the disabled has never surpassed $8.3 \%$ - the historical peak achieved in 2006, the year the new criteria and the size of care benefit were introduced (Český Statistický úrad 2015). The share of budget subsequently fell to $6 \%$ in 2016, below the EU average of $7.1 \%$. Dramatic reframing of the budget concerning the elderly, from $35 \%$ in 1995 to $44 \%$ in 2016 , should be taken as the prior explanation for the reduction in the share for other target groups, including the disabled. The reduction in the share of the social protection budget for people with disabilities coincided with an increase in the participation of the state- $99 \%$ of the budget for care benefits since 2010 is covered by the state in contrast to $80-84 \%$ until 2010 . These two features of the state's role - the reduction in the share of the budget and the increase in the role of state funding-obviously should be seen as one of the explanations for the exaggerated ableism, which infiltrates even the rhetoric of those advocating for the rights of people with ASD.

People with ASD are not guaranteed to get the maximum care benefit even if they need much more for covering the expansion of their services. While officially the cost of personal assistance is 130 Czech crowns (six euros approximately) per hour, the highest level of benefit would cover only 100 hours per month, the minimum number according to the experience of other countries. Also, the cost of personal assistance is fixed and it demotivates potential assistants to work with people with ASD even if their parents are prepared to pay more. In different regions, people with a comparable state of health issues 
could get a different degree of dependence and, as a result, a different amount of benefit. The insufficient amount of the benefit, the complicated procedure for acquiring it, and the obvious arbitrariness in decision making concerning eligibility place this option on the margins of the debates about the ways to improve provision of services. Although the share of personal benefits for people with disabilities has been increasing since 2012 (see Figure 1) as has the number of those eligible to receive the highest possible level of benefit, the main target of debates among the actors is the current scheme of state funding of the services for people with ASD.

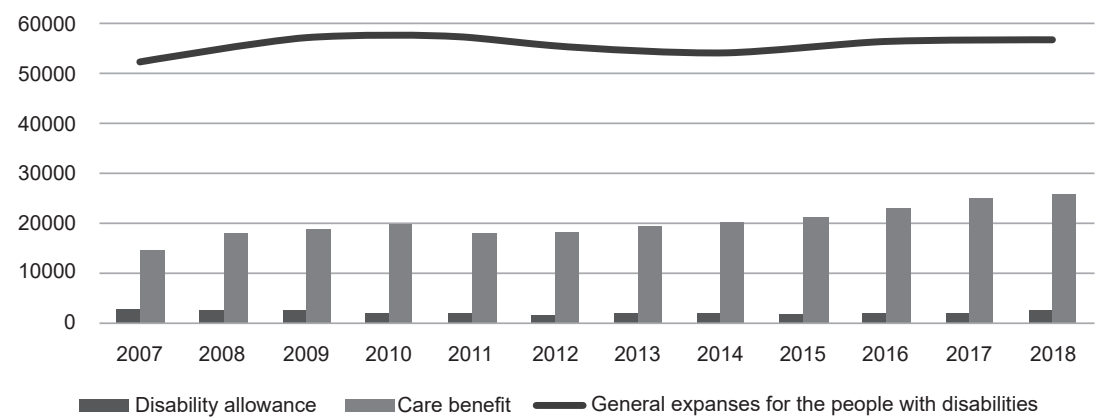

Figure 1. State budget for people with disabilites

Sources: DOTCOM database https://www.disability-europe.net/dotcom; ESSPROS

The analysis by Děti úplňku clearly demonstrates that the entire scheme of funding social services operates in favour of positive discrimination and putting different target groups and relevant services into mutual competition: ' $[t]$ he way to reduce the costs of services is aligned with the importance of the service from the point of view of regional agencies and further options to fund the services by the state' (Křečková, šimáček 2018:39). Each stage of funding the services - making decision about supporting the service, recognizing the amount of support, monitoring the service and reimbursing in the case of overdraft-are accompanied by an enormous number of limits for introducing the services suitable for people with ASD. The services should be registered by the local authorities, and this process takes time, which prevents those who are interested in establishing new services from doing so. Already operating services that provide care for people with ASD mainly are not the services that focus on this group but the services for the people with mental disabilities, which allocate the budget to people with ASD according to the residual principle. In the case of overdrafting, it takes more than ten months for costs to be reimbursed, and family members often give up asking for compensation (Křečková, Šimáček 2018:39). 
While state funding seems to be the central prerequisite for elaborating the services, the main concern is the institutional pathway suitable for ensuring sustainable social provision for people with ASD. Currently, the services for this target groups are supported within program A- the distribution of funds by regional authorities. Many actors, including the representatives of the Ministry of Labour and Social Affairs, tend to fix the task of funding the services within program B - the special budget for particular target groups. David Pospíšil (the Ministry of Labour and Social Affairs) stated: 'Some issues of social services should be solved at the national level and there is a need to fix the finances from the state budget' (Odborná skupina 2015b). Along with this point, Pospísil expressed fears that: 'the Ministry is unable to indicate all gaps and the issue of social services should be solved at regional and local levels' (Ibid). As a possible compromise, non-government actors offered to combine both schemes with priority state funding for crisis intervention and special counselling centres - services that seem to be the most in demand for personal assistance (Křečková, Šimáček 2018: 39).

Following the judgement of the Constitutional Court in favour of a boy with ASD who could not get access to the relevant services, the Ministry announced a plan to fix the budget for special residential institutions for people with ASD who have challenging behaviour (Veselá, Zahradnická 2019). Regions have been facing the issue of funding such services for a long period. Some of the regions solve this task by introducing different elements comparable to a personal budget such as more flexible approach to revising the plans of individual care; avoiding the practice of fixing average costs for the services; introducing special budget for the services aimed at providing care for the people with ASD. Tellingly, these initiatives accompany the regional overcoming one of the main obstacles for developing such practices - the lack of systematic needs assessment: the region had to elaborate its own scheme, the so-called map of needs (karta potřeb) (Pardubický kraj 2018).

\section{Needs assessment: the rule of medics}

After issuing the judgement concerning the case of Autism-Europe v. France (2003), the European Committee of Social Rights has clarified the contents and scope of the protection that EU States must guarantee to people with ASD: 'States shall use a proper definition of autism in their legislation and official documents as point of reference for national definitions should be the one adopted by the World Health Organization' (European Committee 2002). Taking into account the ongoing issues with in-time early diagnosis, some Czech medical experts stress the necessity of commencing intervention even before the official diagnosis in order to prevent aggravation of behavioural issues (Ošlejšková 2008).

Evaluating the changes in the Czech approaches towards assessing needs tends to differentiate between criteria and procedures. Although the experts 
from the Department of Medical Assessment, Ministry of Labour and Social Affairs, claimed massive changes aimed at ensuring an interdisciplinary approach (Čeledová et al. 2014), the organizational framework has not changed significantly and continues to serve the task of indicating the most proper degree of dependence instead of recognizing individual needs. Focusing on positive discrimination of those who have the highest degree of dependency directly fixes the central role of physicians as experts. The Law on Social Service (2006) requires indicating the dependence on the care of the third person as a 'result of long-term unfavourable state of health and lost capacities to cope with basic living needs'. Practically, this meant that the role of medical diagnosis remained as the main eligibility criterion for making a decision on benefits and their extent. Even more, the physician is only a professional who makes decision on changing the degree of dependence in case of deterioration (Pastorková 2015).

Although physicians are the key experts, the obvious lack of professionals significantly aggravates the assessment of the needs due to extreme overloading of such professionals. Instead of 388 services, only 323 are in operation, which increases the period of decision making to an average of 53 days. The lack of physicians comes with an increasing load. The number of requests to assess the degree of dependence dramatically increased from 608 cases annually per physician to 1422 in 2016 (Koubová 2017).

A powerful but not resourceful system of medical expertise operates much worse for people with ASD. Civil activists stress the absence of individual assessments and the rupture between medical diagnosis and further complex assessment of needs (Křečková, Šimáček 2018:40). Dušan Babuš (Ministry of Health) admitted the necessity of an alternative approach to evaluating the mental state and handicaps of people with ASD not directly submitted for formal diagnosis (Odborná skupina 2015a). Also, the Government Board continues to prescribe the task of improving the assessment of needs to the Ministry of Health (Vláda ČR 2016). According to the Ombudsman, reproducing medical focus in assessment remains one of the main obstacles for involving regional authorities in planning and progressing the services for people with ASD (Veřejný ochránce 2018b).

\section{Provision: univocity with residential care}

The survey conducted by the HR Ombudsman among the regional authorities indicates an ambivalent attitude to the provision of services for people with ASD. While the majority of respondents report the existence of services, all of them agree with the limited access to social provision because of the lack of staff and placement capacities. Mapping the regional networking indicates the priority of residential care- more than half of the respondents mention residential care units for people with disabilities (domov pro osoby se zdravotním postižením) and residential care units with special conditions (domov se zvláštním režimem). 
Along with it, more than half of the regions offer day care services for adults with ASD. The regions intend to practise short-term placements of people with ASD under residential care than to cooperate with the families in order to maintain the natural habitat. Generally, the range of services for adults is wider than for children, and those older than eighteen have more options of community care but less than the other target groups of people with disabilities.

While the assessment of needs is limited by the task of establishing the relation between the level of dependence and the size of the benefit, elaborating a care plan remains the responsibility of the particular service after accepting a client's application. Only after affiliating with a particular service, the family or the person with disabilities could ask to revise the plan or complain of insufficient care. This arbitrariness from the side of services is aggravated by the well-spread practice of services limiting access of people with challenging behaviour by using a negative approach to defining the range of potential clients, those who would be not accepted due to the absence of relevant services or resources (Odborná skupina 2019). The current work-loading conditions and the trend of services avoiding expenses for retraining of their staff due to limited budgets determine the huge employee turnover as well as the practice of recruiting students of helping professions who can work part-time only (Křečková, Šimáček 2018:44). This tends to medicalize residential care for people with ASD (Odborná skupina 2015a).

Squeezed by the limited range of services and limited access, people with ASD try to elaborate pilot projects targeted at introducing new types of services. One recent initiative introduced home-sharing, offering families the opportunity to participate in the care of people with ASD by accepting them for a set period (Děti úplňku 2019). In spite of the great potential of such projects for informing and involving communities into solving the issue of services for people with ASD, these initiatives do not dovetail enough with the call for systematic reform of personal assistance.

\section{Conclusion}

The current organisational approach to provide the needs of the people with ASD in Czechia does not meet the challenge of individual assistance. The main issue is the existence of multiple gaps in the different stages of planning and implementing care. Filling these gaps requires a set of strategies and actors willing and being able to solve the task to individualise the care for people with ASD. Possible vehicles of solving this task, either networking of existing services or making health care facilities more open to interdisciplinary approach to ASD, should be discussed in terms of existing human resources and the options for retraining/supervision for that professionals who would be involved in such changes.

Besides, there is a factor of regional variety - the strategy of introducing individual assistance could be varied from region to region. The desired transfor- 
mation towards more thoughtful approach for planning and implementing intervention calls for coherent changes in the criteria and procedures of evaluating the needs of the people with ASD. Lack of experts in many regions and the irregular legitimation of ASD as a disease among the Czech health care practitioners remains a main risk for introducing individual assistance.

The task of finding persuasive arguments for those who are gate keepers (public figures, politicians) is another concern for an expert discussion. To which degree can the current international trends in assessing the needs of the people with ASD influence the practices and policies in Czechia? In which extension should the changes concerning the needs of people with ASD be related to the general issues of welfare policy towards the people with disabilities? These questions turn the analysis of the current state of the assessment and intervention with the people with ASD to the plan of particular steps towards implementing the changes.

\section{Acknowledgment}

The research was sponsored by the Grant Agency of the Czech Republic, as part of the project 'Child Welfare Discourses and Practices in the Czech Lands: The Segregation of Roma and Disabled Children during the Nineteenth and Twentieth Centuries' (GA15-10625S).

\section{References}

Autism Policy and Politics (2015) Autism ID Cards. Available at: http://www.autismpolicyblog.com/2015/01/autism-id-cards.html (accessed 5 April 2019).

Cage E., Monaco J.D., Newell V. (2018) Experiences of Autism Acceptance and Mental Health in Autistic Adults. Journal of Autism and Developmental Disorders, 48 (2):473-484.

Čeledová L., Čevela R., Ornerová A. (2014) Roční zkušenosti s posuzováním stupně závislosti pro účely příspěvku na péči. Praktický lékař, 94 (2): 84-88.

Český statistický úřad (2015) Výdaje na sociální ochranu v ČR podle základního systému ESSPROS (1995-2014). Available at: https:/www.czso.cz/documents/10180/34280637/19002916 text.pdf/4c45a820-07dd-4e26-a977-9a34e208d295?version=1.1 (accessed 5 April 2019).

Děti úplňku (2017) Kdo jsme. Available at: https://www.detiuplnku.cz/cs/kdo-jsme/ (accessed 5 April 2019).

Děti úplňku (2019) Homesharing. Available at: https://www.detiuplnku.cz/cs/homesharing/ (accessed 5 April 2019).

ENIL (2016) What is Personal Assistance? Available at: http://enil.eu/wp-content/uploads/2016/06/FAQ_Personal_Assistance.pdf (accessed 5 April 2019).

European Committee on Social Rights (2002) Reclamation Collective No 13/2002 Autisme Europe c. France. Available at: https://juridique.defenseurdesdroits.fr/doc_num.php?explnum _ $\mathrm{id}=6061$ (accessed 5 April 2019). 
Jaarsma P., Welin S. (2012) Autism as a Natural Human Variation: Claims of the Neurodiversity Movement. Health Care Analysis, 20 (1):20-30.

Jůn H., Thorová K. (2017) Současná situace okolo pobytových služeb pro osoby s autismem a souběhem chování náročného na péči. Zpravodaj Asociace poskytovatelů služeb pro osoby s PAS, (4): 10-11.

Gobbo K., Shmulsky S. (2016) Autistic Identity Development and Postsecondary Education. Disability Studies Quarterly, (36). Available at: http://dsq-sds.org/article/view/5053 (accessed 29 July 2019).

Koubová M. (2017) Co s nedostatkem posudkových lékařru? Část nahradime asistenty, část smluvnimi doktory, doufá MPSV. Available at: http://www.zdravotnickydenik.cz/2017/03/ co-s-nedostatkem-posudkovych-lekaru-cast-nahradime-asistenty-cast-smluvnimi-doktory-doufa-mpsv/ (accessed 5 April 2019).

Křečková M., Šimáček M. (2018) Dostupnost služeb pro lidi s poruchou autistického spektra v ČR a Evropě-analýza a inspirace. Available at: https://www.detiuplnku.cz/wp-content/ uploads/2018/11/Deti-uplnku-analyza-dostupnosti-sluzeb_e.pdf (accessed 5 April 2019).

Lawson W. (2008) Life and Learning with Autistic Spectrum Diffability. Jessica Kingsley Publishers DVD.

Lim Ch. (2015) Accommodating Autistics and Treating Autism: Can We Have Both? Bioethics, 29 (8): 564-572.

Matýs J. (2017) Autismus je šlágr. Reflex, 30 (3). Available at: https://www.reflex.cz/clanek/ archiv-hlavni-clanky/78446/autismus-je-slagr.html (accessed 29 July 2019).

Mladenov T. (2016) Postsocialist Disability Matrix. Scandinavian Journal of Disability Research. Available at: https://doi.org/10.1080/15017419.2016 (accessed 5 April 2019).

Mladenov T., Pokern Y., Cojocariu I. (2019) Personal Assistance Checklist-A Tool for Assessing Personal Assistance Schemes. European Network of Independent Life.

MPSV (2008) Tisková zprava: Od 1. ledna 2007 se změní systém sociálních služeb. Available at: https://www.mpsv.cz/files/clanky/2626/280306a.pdf (accessed 5 April 2019).

Ministerstvo zdravotnictví [Ministry of Health] (2016) Postup prací na implementaci návrhů uvedených $\mathbf{v}$ materiálu Podnět $k$ řešeni života osob s PAS a jejich rodin [The Actions Towards Implementing the Plan of Solving the Issues of the People with ASD and Their Families] Prague.

Odborná skupina VVZPO (2015a) Zápis ze zasedání: 27.03.2015. Available at: https://www. vlada.cz/cz/ppov/vvzpo/odborne-skupiny/pro-problematiku-osob-s-pas/jednani-27—brezna-2015-129637/ (accessed 5 April 2019).

Odborná skupina VVZPO (2015b) Zápis ze zasedání: 04.09.2015. Available at: https://www. vlada.cz/cz/ppov/vvzpo/odborne-skupiny/pro-problematiku-osob-s-pas/jednani-4zari-2015-134716/ (accessed 5 April 2019).

Odborná skupina VVZPO (2015c) Zápis ze zasedání: 06.11.2015. Available at: https://www. vlada.cz/cz/ppov/vvzpo/odborne-skupiny/pro-problematiku-osob-s-pas/jednani-6 - listopadu-2015-137175/ (accessed 5 April 2019).

Odborná skupina VVZPO (2019) Zápis ze zasedání: 22.01.2019 Available at: https://www. vlada.cz/cz/ppov/vvzpo/odborne-skupiny/pro-problematiku-osob-s-pas/jednani-22-ledna-2019-171965/ (accessed 5 April 2019). 
OHCHR (2010) Monitoring the Convention on the Rights of Persons with Disabilities: Guidance for Human Rights Monitors. Professional Training Series, 17. Available at: https://www. ohchr.org/documents/Publications/disabilities_training_17en.pdf_accessed 5 April 2019).

Palmisano G. (2015) The Protection of People with Autism in the Framework of the Council of Europe and the European Union. In: V. Della, F. R. Cera (eds.) Protecting the Rights of People with Autism in the Fields of Education and Employment: International, European and National Perspectives. London: Routlegde: 11-23.

Pardubický kraj (2018) Vyjádřeni Pardubického kraje k zaslaným doporučením veřejné ochránkyně práv ke zlepšeni dostupnosti sociálnich služeb pro déti a dospěly osoba s PAS. Available at: https:// www.ochrance.cz/fileadmin/user_upload/CRPD/autismus/Pardubicky-kraj-vyjadreni.pdf (accessed 5 April 2019).

Pastorková R. (2015) Funkční př́istup k posuzování stupnězávislosti. Reviznía posudkové lékařství, 18 (1):3-7.

Sinecka J. (2007) Disability Law in the Czech Republic: A Case. StudyDisability Studies Quarterly, 27 (1-2). Available at: http://dsq-sds.org/article/view/14/14 (accessed 5 April 2019).

Slepičková L., Vad’urová H., Pančocha K. (2019) Screening PAS: Zkušenosti českých pediatrů. XX Mezinárodní konference k problematice osob se specifickými potřebami, Olomouc 19-20.3. 2019.

Solomon A. (2012) Far from the Tree: Parents, Children and the Search for Identity. New York: Scribner.

Veřejný ochránce práv (2018a) Dostupnost sociálnich služeb pro osoby s poruchou autistického spektra: Výzkum veřejné ochránkyně práv. Available at: https://www.ochrance. cz/fileadmin/user_upload/CRPD/autismus/Vyzkum-autisti.pdf (accessed 5 April 2019).

Veřejný ochránce práv (2018b) Doporučeni veřejné ochránkyně práv ke zlepšení dostupnosti sociálnich služeb. Available at: https://www.ochrance.cz/fileadmin/user_upload/CRPD/autismus/Doporuceni-autisti.pdf (accessed 5 April 2019).

Veselá L., Zahradnická E. (2019) Šest let beznaděje. Matka hledá místo pro autistické ditě, marně. Available at: https://www.idnes.cz/zpravy/domaci/postizeni-autismus-rettuv-syndrom-pobytove-zarizeni.A190110_114920_domaci_bur?_(accessed 5 April 2019).

Vláda ČR (2016) Usnesení č. 111/2016 Podnět $k$ řešení situace života osob s poruchou autistického spektra a jejich rodin. Available at: https://www.vlada.cz/assets/ppov/vvzpo/dokumenty/Podnet-k-reseni-situace-PAS.pdf (accessed 5 April 2019). 